Justyński, dr hab. Mateusz Nieć, prof. AI, dr Jacek Janowski i dr Piotr Szymaniec. Obrady drugiej części tejże sekcji, już pod przewodnictwem dr. hab. Adama Bosiackiego, prof. UW, rozpoczął dr hab. Mariusz Jagielski (UŚ), który przedstawił referat „Naród jako suweren. Mechanizmy wpływu i kontroli”. Następnie referaty przedstawili dr hab. Mateusz Nieć, prof. AI, „Czwarta władza - refleksja o władzy i panowaniu”; mgr Paweł Fiktus (UWr) i dr Piotr Szymaniec, „Spory wokół Machiavellego we współczesnych badaniach nad myślą polityczną i prawną"; mgr Michał Rybicki (UŁ), „Metapolityczna koncepcja Michaela Oakshotta". W dyskusji wzięli udział prof. dr hab. Janusz Justyński, prof. dr Adam Czarnota i dr hab. Mirosław Sadowski.

Drugi dzień obrad zakończył się prezentacją dokonań naukowych i dydaktycznych większości katedr doktryn politycznych i prawnych w Polsce. Przedstawiciele poszczególnych ośrodków akademickich mówili o wydanych książkach, przeprowadzonych postępowaniach habilitacyjnych, obronionych pracach doktorskich, prowadzonych przedmiotach $\mathrm{w}$ swoich katedrach i innych osiągnięciach pracowników i doktorantów.

Prezentacje dorobku naukowego zamknęły doroczny Zjazd Katedr Doktryn Politycznych i Prawnych, zorganizowany w Szklarskiej Porębie. Materiały Zjazdu zostaną staraniem organizatorów opublikowane $\mathrm{w}$ tomie pokonferencyjnym.

ŁUKASZ SZYMAŃSKI (Wrocław)

\title{
KOLOKWIUM HABILITACYJNE DR MARZENY PASZKOWSKIEJ
}

W dniu 10 października $2011 \mathrm{r}$. na Wydziale Prawa i Administracji Uniwersytetu Warszawskiego odbyło się kolokwium habilitacyjne dr Marzeny Paszkowskiej. Podstawą przewodu była monografia Nauka prawa karnego w środowisku ,Gazety Sadowej Warszawskiej". Recenzentami pracy i dorobku byli: prof. dr hab. Danuta Janicka (Uniwersytet Mikołaja Kopernika), prof. dr hab. Katarzyna Sójka-Zielińska (Uniwersytet Warszawski), prof. dr hab. Wojciech Witkowski (Uniwersytet Marii Curie-Skłodowskiej) oraz prof. dr hab. Marian Mikołajczyk (Uniwersytet Sląski).

Po wystąpieniu recenzentów i dyskusji Rada przyjęła kolokwium habilitacyjne. Następnie habilitantka wygłosiła wykład Udziat polskich uczonych karnistów w międzynarodowym ruchu naukowym na przełomie XIX $i$ XX w. Po nim Rada Wydziału podjęła uchwałę o nadaniu dr Marzenie Paszkowskiej stopnia doktora habilitowanego. 